\title{
ANALISIS KINERJA APARATUR SIPIL NEGARA PADA BADAN PENGEMBANGAN SUMBER DAYA MANUSIA DAERAH PROVINSI NUSA TENGGARA TIMUR
}

\author{
Gregorius Mau Tae
}

\author{
Program Studi Magister Manajemen, Fakultas Ekonomika dan \\ Bisnis, Universitas Katolik Widya Mandira
}

\author{
gregoriustae@gmail.com
}

Abstract
The purpose of this study was to determine the description of the performance,
work motivation, work discipline, organizational culture, work environment, and HR
competencies at the Regional Human Resources Development Agency (BPSDMD)
of NTT Province. To determine work discipline partially, corporate culture, work
environment, and HR competence have a positive and significant effect on ASN
work motivation at BPSDMD NTT Province. To find out partially work discipline,
organizational culture, work environment, HR competence, and work motivation
positively affect ASN performance at BPSDMD NTT Province. Work has a positive
and significant impact in mediating the influence of work discipline, organizational
culture, work environment, and HR competence on ASN performance at BPSDMD
NTT Province. This research uses quantitative methods. The sample of this
research is the staff of BPSDMD NTT Province, as many as 55 people. Data were
collected using a questionnaire and analyzed using the SmartPLS application.
The inner model test shows that work discipline, organizational culture, work
environment, and HR competence partially positively and significantly affect work
motivation. Because the probability values of work discipline, corporate culture,
work environment, HR competence, and work motivation partly have a positive and
significant effect on employee performance. The Specific Indirect Effect test results
show that work motivation has a positive and significant impact in mediating the
influence of work discipline, organizational culture, work environment, and HR
competence on ASN performance.
Keywords: Performance, Work Motivation, Work Discipline, Organizational Culture,
Work Environment, HR Competence




\section{PENDAHULUAN}

Aparatur Sipil Negara merupakan sumber daya manusia yang menunjang pencapaian target kerja pemerintah. Salah satu organisasi perangkat daerah yang merupaka bagian penting dari pemerintah adalah Badan Pengembangan Sumber Daya Manusia Daerah (BPSDMD) Provinsi Nusa Tenggara Timur. Dalam Peraturan Daerah Provinsi Nusa Tenggara Timur Nomor 9 Tahun 2016 tentang Pembentukan dan Susunan Perangkat Daerah Provinsi Nusa Tenggara Timur, disebutkan bahwa tugas dari BPSDMD Provinsi Nusa Tenggara Timur adalah membantu Gubernur melaksanakan fungsi Penunjang Urusan Pemerintahan Bidang Pendidikan dan Pelatihan yang menjadi Kewenangan Daerah.

Indikator Kinerja Utama atau IKU adalah ukuran atau indikator kinerja suatu instansi, utamanya dalam mencapai tujuan dan sasaran tertentu. Setiap lembaga atau instansi pemerintah wajib merumuskan indikator kinerja utama agar dapat mengetahui kinerja instansi. Berdasarkan data penilaian IKU, diketahui bahwa dari 6 sasaran strategis yang telah ditetapkan, hanya 2 sasaran yang mengalami kenaikan pada Tahun 2020 yaitu meningkatnya kompetensi ASN dan meningkatnya sarana kediklatan berbasis digital. Sedangkan4 sasaran strategis lainnya mengalami penurunan jika dibandingkan dengan capaian Tahun 2019. Hal ini mengindikasikan bahwa terdapat permasalahan dalam upaya mencapai sasaran strategis Badan Pengembangan Sumber Daya Manusia Daerah Provinsi Nusa Tenggara Timur.

Salah satu faktor yang menunjang pencapaian target dalam organisasi adalah kinerja dari pegawai dalam organisasi tersebut. Selanjutnya, tinggi rendahnya kinerja seorang pegawai ditentukan oleh faktor-faktor yang mempengaruhi baik secara langsung maupun tidak langsung. Menurut Simanjuntak (2011), kinerja seseorang dapat dipengaruhi oleh beberapa faktor yang dapat digolongkan menjadi 3 (tiga), yaitu: kompetensi individu, dukungan organisasi, dan dukungan manajemen. Afandi (2018) menyatakan bahwa faktor yang mempengaruhi kinerja antara lain: kemampuan, kepribadian, minat kerja, kejelasan tugas, motivasi kerja, kompetensi, lingkungan kerja, budaya organisasi, kepemimpinan dan disiplin kerja. Dalam penelitian ini, akan difokuskan pada faktor motivasi kerja, disiplin kerja, budaya organisasi, lingkungan kerja dan kompetensi.

Berdasarkan teori, permasalahan dan research gap yang telah dijelaskan pada latar belakang penulisan ini, maka penulis tertarik untuk melakukan penelitian dengan judul "Analisis Kinerja Aparatur Sipil Negara (ASN) pada Badan Pengembangan Sumber Daya Manusia Daerah Provinsi Nusa Tenggara Timur".

\section{KAJIAN PUSTAKA}

\subsection{Kinerja}

Kualitas kinerja baik para aparatur negara menjadi kebutuhan yang penting dalam mendukung keberhasilan pembangunan secara nasional maupun 
pembangunan daerah. Rivai (Sandy, 2015) menyatakan kinerja atau prestasi kerja adalah hasil atau tingkat keberhasilan seseorang secara keseluruhan selama periode tertentu didalam melaksanakan tugas dibandingkan dengan berbagai kemungkinan, seperti standar hasil kerja, target atau sasaran atau kriteria yang telah ditentukan terlebih dahulu dan disepakati bersama.

\subsection{Motivasi Kerja}

Motivasi adalah proses yang berperan pada intensitas, arah, dan lamanya berlangsung upaya individu ke arah pencapaian sasaran (Robbins, 2009). Motivasi adalah keinginan dalam diri seseorang yang menyebabkan orang tersebut bertindak. Orang biasanya bertindak karena suatu alasan untuk mencapai tujuan. Jadi motivasi adalah sebuah dorongan yang diatur oleh sebuah tujuan dan jarang muncul dalam kekosongan. Kata kata kebutuhan, keinginan, hasrat, dan dorongan, semuanya serupa dengan motif yang merupakan asal dari kata motivasi (Mathis dan Jackson, 2006).

\subsection{Disiplin Kerja}

Hasibuan (2016) mengemukakan bahwa disiplin kerja adalah kesadaran dan kesediaan seseorang dalam mentaati semua peraturan perusahaan dan normanorma sosial yang berlaku. Kesadaran adalah sikap seseorang yang secara sukarela menaati semua peraturan dan sadar akan tugas dan tanggung jawabnya. Jadi dia akan mematuhi/mengerjakan semua tugasnya dengan baik, bukan atas paksaan. Kesediaan adalah suatu sikap, tingkah laku dan perbuatan seseorang yang sesuai dengan peraturan perusahaan, baik tertulis maupun tidak.

\subsection{Budaya Organisasi}

Budaya telah lama menjadi konsep penting untuk memahami masyarakat dan kelompok manusia. Dari budaya dapat dilihat perbedaan mengenai cara para anggota kelompok atau masyarakat tertentu saling berinteraksi dengan orang lain dan bagaimana mereka menyelesaikan apa yang dikerjakan. Budaya juga merupakan pengetahuan yang dapat dikomunikasikan. Melalui budaya dapat dipelajari sifat-sifat perilaku yang ada pada anggota-anggota kelompok dan wujudnya dalam lembaga-lembaga dan artifak-artifak mereka. Suatu organisasi akan berhasil atau gagal, sebagian besar ditentukan oleh budaya yang ada pada organisasi tersebut. Menurut Stoner dalam Winardi (2002), budaya organisasi yang kuat merupakan alasan suksesnya organisasi. Sebaliknya budaya kuat yang sama sekali sukar berubah disebutkan menjadi penyebab masalah organisasi.

\subsection{Lingkungan Kerja}

Lingkungan kerja dalam suatu organisasi penting untuk diperhatikan manajemen karena lingkungan kerja mempunyai pengaruh langsung terhadap para karyawan yang melakukan aktivitas kerja. Umar dalam Afandi (2018), menyatakan bahwa lingkungan kerja adalah sesuatu yang ada di lingkungan para pekerja yang 
dapat mempengaruhi dirinya dalam menjalankan tugas seperti temperature, kelembaban, ventilasi, penerangan, kegaduhan, kebersihan tempat kerja dan ketersediaan alat perlengkapan kerja yang layak pakai.

\subsection{Kompetensi SDM}

Setiap organisasi dibentuk untuk mencapai tujuan tertentu dan untuk mencapainya diperlukan dukungan dari berbagai aspek. Salah satu aspek tersebut adalah kompetensi para anggota organisasi. Barney dalam Mangkunegara (2017) berpendapat bahwa salah satu sumber daya yang dibutuhkan organisasi adalah pegawai yang memiliki kompetensi sesuai bidang kerja organisasi tersebut. Menurut Fahmi (2016), kompetensi pegawai adalah suatu kemampuan yang dimiliki oleh seorang pegawai, yang memiliki nilai jual dan terlihat dari hasil kerja serta inovasi yang dihasilkan.

\subsection{Kerangka Pemikiran}

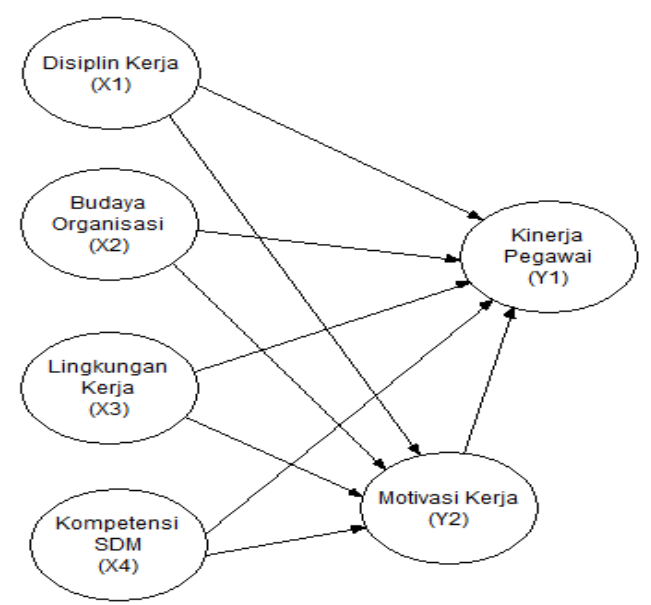

Gambar 1. Model Penelitian

Berdasarkan kerangka pemikiran tersebut, dapat diajukan hipotesis sebagai berikut:

1. Kinerja, motivasi kerja, disiplin kerja, budaya organisasi, lingkungan kerja dan kompetensi SDM pada Badan Pengembangan Sumber Daya Manusia Daerah Provinsi Nusa Tenggara Timur cukup baik

2. Disiplin kerja, budaya organisasi, lingkungan kerja dan kompetensi SDM secara parsial berpengaruh positif dan signifikan terhadap motivasi kerja ASN pada Badan Pengembangan Sumber Daya Manusia Daerah Provinsi Nusa Tenggara Timur.

3. Disiplin kerja, budaya organisasi, lingkungan kerja, kompetensi SDM dan motivasi kerja secara parsial berpengaruh positif dan signifikan terhadap kinerja ASN pada Badan Pengembangan Sumber Daya Manusia Daerah Provinsi Nusa Tenggara Timur. 
4. Motivasi kerja secara parsial berpengaruh positif dan signifikan dalam memediasi pengaruh disiplin kerja, budaya organisasi, lingkungan kerja dan kompetensi SDM terhadap kinerja ASN pada Badan Pengembangan Sumber Daya Manusia Daerah Provinsi Nusa Tenggara Timur

\section{METODOLOGI PENELITIAN}

Penelitian ini termasuk jenis penelitian kuantitatif. Tempat penelitian pada Badan Pengembangan Sumber Daya Manusia Daerah Provinsi Nusa Tenggara Timur. Waktu penelitian berlangsung dari bulan Februari s/d Juni 2021. Populasi dalam penelitian ini meliputi staf Badan Pengembangan Sumber Daya Manusia Daerah Provinsi Nusa Tenggara Timur sebanyak 55 orang. Dalam penelitian ini menggunakan alat uji statistic yaitu dengan uji persamaan structural berbasis variance atau yang lebih dikenal dengan nama Partial Least Square (PLS) menggunakan software SmartPLS 3.0.

\section{HASIL DAN PEMBAHASAN}

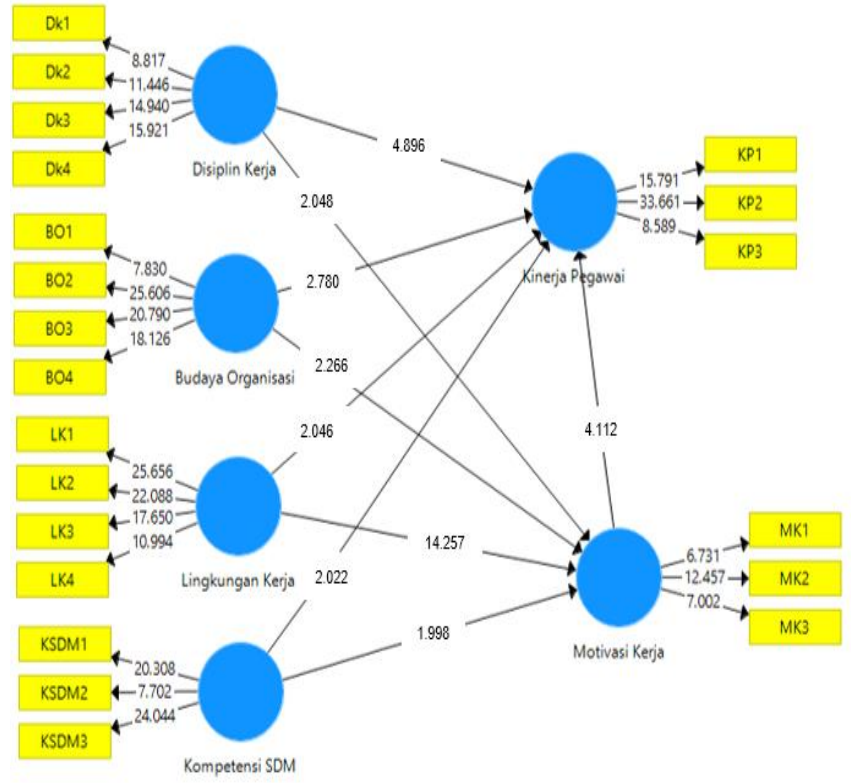

Gambar 2. Hasil Uji Inner Model

\subsection{Pengaruh Disiplin Kerja terhadap Motivasi Kerja ASN pada Badan} Pengembangan Sumber Daya Manusia Daerah Provinsi NTT

Hasil uji statistik menunjukkan bahwa nilai probability yang diperoleh adalah sebesar 0,043 $(<0,05)$, sehingga keputusannya adalah disiplin kerja berpengaruh positif dan signifikan terhadap motivasi kerja. Hasil penelitian ini sejalan dengan penelitian yang dilakukan oleh Rosento (2019) dengan judul "Pengaruh Disiplin Kerja Terhadap Motivasi Karyawan Pada PT. Trisentosa Adhirajasa Jakarta" di mana diperoleh hasil bahwa disiplin kerja memiliki pengaruh dan hubungan kuat terhadap motivasi karyawan Pada PT. Trisentosa Adhirajasa Jakarta. 
Hasil penelitian ini juga sesuai dengan pendapat Simamora dalam Safudin (2019) yang mengemukakan bahwa disiplin kerja adalah bentuk pengendalian diri pegawai dan pelaksanaan yang teratur menunjukan tingkat kesungguhan tim kerja dalam organisasi. Disiplin kerja digunakan terutama untuk memotivasi karyawan agar data mendisplinkan diri dalam melaksanakan pekerjaan, baik secara perorangan maupun kelompok dan disiplin kerja sangat penting dalam usaha organisasi untuk mencapai tujuannya, sehingga berbagai kegiatan harus dilakukan untuk meningkatkan disiplin kerja dengan cara memberikan motivasi.

\subsection{Pengaruh Budaya Organisasi terhadap Motivasi Kerja ASN pada Badan Pengembangan Sumber Daya Manusia Daerah Provinsi NTT}

Hasil uji statistik menunjukkan bahwa nilai probability yang diperoleh adalah sebesar $0,024(<0,05)$, sehingga keputusannya adalah budaya organisasi berpengaruh positif dan signifikan terhadap motivasi kerja.Hasil penelitian ini sejalan dengan penelitian yang dilakukan oleh Giantari (2017) dengan judul "Pengaruh Budaya Organisasi Terhadap Motivasi Kerja Dan Kinerja Karyawan Klumpu Bali Resort Sanur" yang memperoleh hasil bahwa Budaya organisasi berpengaruh positif dan signifikan terhadap motivasi kerja karyawan, semakin baik budaya organisasi maka semakin tinggi tingkat motivasi kerja yang dimiliki oleh karyawan. Hasil penelitian ini sesuai dengan pendapat Cemal (2012) yang menyatakan bahwa motivasi kerja adalah proses penentuan seberapa banyak tindakan atau usaha yang dicurahkan dalam melaksanakan pekerjaan dalam organisasi, dan untuk mendukung motivasi kerja pegawai maka dibutuhkan adanya budaya organisasi yang baik.

\subsection{Pengaruh Lingkungan Kerja terhadap Motivasi Kerja ASN pada Badan Pengembangan Sumber Daya Manusia Daerah Provinsi NTT}

Hasil uji statistik menunjukkan bahwa nilai probability yang diperoleh adalah sebesar $0,000 \quad(<0,05)$, sehingga keputusannya adalah lingkungan kerja berpengaruh positif dan signifikan terhadap motivasi kerja. Hasil penelitian ini sejalan dengan penelitian Prakoso (2014), "Pengaruh Lingkungan Kerja Terhadap Motivasi Kerja dan Kinerja Karyawan (Studi Pada Karyawan PT. AXA Financial Indonesia Cabang Malang)" di mana diperoleh hasil bahwa lingkungan kerja secara parsial berpengaruh signifikan terhadap motivasi kerja Karyawan PT. AXA Financial Indonesia Cabang Malang. Hasil penelitian ini sejalan dengan pendapat Edison (2017) yang mengemukakan bahwa lingkungan kerja yang nyaman dan kondusif dapat mempengaruhi karyawan untuk lebih termotivasi dalam meningkatkan kualitas dan kuantitas kinerjanya agar lebih efektif dan efisien, sehingga lingkungan kerja dapat berpengaruh dalam meningkatkan motivasi kerja. 


\subsection{Pengaruh Kompetensi SDM terhadap Motivasi Kerja ASN pada Badan Pengembangan Sumber Daya Manusia Daerah Provinsi NTT}

Hasil uji statistik menunjukkan bahwa nilai probability yang diperoleh adalah sebesar 0,044 $(<0,05)$, sehingga keputusannya adalah kompetensi SDM berpengaruh positif dan signifikan terhadap motivasi kerja. Hasil penelitian ini sejalan dengan penelitian yang dilakukan oleh Khori (2013) dengan judul "Pengaruh Kompetensi SDM Terhadap Motivasi Kerja Pegawai Perpustakaan di Universitas Negeri Yogyakarta" yang menunjukkan hasil bahwa trdapat pengaruh yang signifikan antara kompetensi SDM terhadap motivasi kerja pegawai perpustakaan di Universitas Negeri Yogyakarta. Menurut Herzberg yang dikutip oleh Anoraga (2009) menyatakan bahwa kompetensi merupakan salah satu faktor yang mempengaruhi motivasi kerja. Dharma dalam Sutrisno (2009) bahwa kompetensi selalu mengandung maksud atau tujuan, di mana merupakan dorongan motif atau trait yang menyebabkan suatu tindakan untuk memperoleh suatu hasil.

\subsection{Pengaruh Disiplin Kerja terhadap Kinerja Pegawai pada Badan Pengembangan Sumber Daya Manusia Daerah Provinsi NTT}

Hasil uji statistik menunjukkan bahwa nilai probability yang diperoleh adalah sebesar $0,000(<0,05)$, sehingga keputusannya adalah disiplin kerja berpengaruh positif dan signifikan terhadap kinerja pegawai. Hasil penelitian ini sejalan dengan penelitian yang dilakukan Hapid dan Sunarwan (2014) dengan judul " Pengaruh Kepemimpinan, Motivasi dan Disiplin Kerja Terhadap Kinerja Karyawan PT. Financia Multi Finance Palopo" yang menunjukkan hasil bahwa disiplin kerja berpengauh signifikan terhadap berpengaruh positif terhadap Kinerja Karyawan PT. Financia Multi Finance Palopo. Disiplin dilaksanakan untuk mendorong para pegawai agar mengikuti berbagai standar dan aturan, sehingga penyelewenganpenyelewengan dapat dicegah. Sasaran pokoknya adalah untuk mendorong disiplin diri diantara pegawai untuk datang tepat waktu. Dengan datang tepat waktu dan melaksanakan tugas sesuai dengan tugasnya, maka diharapkan kinerja akan meningkat. Melalui disiplin akan mencerminkan kekuatan, karena biasanya seseorang yang berhasil dalam karyanya adalah mereka yang memiliki disiplin tinggi. Guna mewujudkan organisasi yang pertama harus dibangun dan ditegakkan diperusahaan tersebut adalah kedisplinan pegawai.

\subsection{Pengaruh Budaya Organisasi terhadap Kinerja Pegawai pada Badan Pengembangan Sumber Daya Manusia Daerah Provinsi NTT}

Hasil uji statistik menunjukkan bahwa nilai probability yang diperoleh adalah sebesar $0,006 \quad(<0,05)$, sehingga keputusannya adalah budaya organisasi berpengaruh positif dan signifikan terhadap kinerja pegawai. Hasil penelitian ini sejalan dengan penelitian yang dilakukan Hapid dan Fitri (2014) dengan judul "Pengaruh Budaya Organisasi dan Motivasi Kerja Terhadap Kinerja Pegawai di 
Kantor Regional I Badan Kepegawaian Negara Yogyakarta " yang menunjukkan hasil bahwa terdapat pengaruh positif dan signifikan dari budaya organisasi terhadap kinerja pegawai Kantor Regional I Badan Kepegawaian Negara Yogyakarta. Hasil penelitian ini juga sejalan dengan pendapat Armstrong dalam Sudarmanto (2009:182) yang menyatakan bahwa budaya organisasi merupakan komponen kunci dalam pencapaian misi dan strategi organisasi secara efektif dan manajemen perubahan. Budaya dapat menciptakan lingkungan kerja yang kondusif untuk perbaikan kinerja dan manajemen perubahan.

\subsection{Pengaruh Lingkungan Kerja terhadap Kinerja Pegawai pada Badan Pengembangan Sumber Daya Manusia Daerah Provinsi NTT}

Hasil uji statistik menunjukkan bahwa nilai probability yang diperoleh adalah sebesar 0,041 $(<0,05)$, sehingga keputusannya adalah lingkungan kerja berpengaruh positif dan signifikan terhadap kinerja pegawai. Hasil penelitian ini sejalan dengan penelitian yang dilakukan Hapid dan Fitri (2014) dengan judul "Pengaruh Budaya Organisasi dan Motivasi Kerja Terhadap Kinerja Pegawai di Kantor Regional I Badan Kepegawaian Negara Yogyakarta " yang menunjukkan hasil bahwa terdapat pengaruh positif dan signifikan dari budaya organisasi terhadap kinerja pegawai Kantor Regional I Badan Kepegawaian Negara Yogyakarta. Hasil dari penelitian ini didukung oleh pendapat Reksohadiprodjo (2000:151) yang menyatakan bahwa lingkungan kerja yang buruk akan mempengaruhi pekerja karena pekerja merasa terganggu dalam pekerjaannya, hingga tidak dapat mencurahkan perhatian terhadap pekerjaannya, sehingga mengakibatkan kinerja karyawan menjadi menurun.

\subsection{Pengaruh Kompetensi SDM terhadap Kinerja Pegawai pada Badan Pengembangan Sumber Daya Manusia Daerah Provinsi NTT}

Hasil uji statistik menunjukkan bahwa nilai probability yang diperoleh adalah sebesar $0,021 \quad(<0,05)$, sehingga keputusannya adalah kompetensi SDM berpengaruh positif dan signifikan terhadap kinerja pegawai. Hasil penelitian ini sejalan dengan penelitian yang dilakukan Alam (2019) (2014) dengan judul: "Pengaruh Kompetensi dan Budaya Organisasi Terhadap Kinerja Melalui Disiplin Kerja Pegawai Politeknik IImu Pelayaran Makassar" yang menunjukkan hasil bahwa kompetensi pegawai berpengaruh terhadap kinerja pegawai Politeknik IImu Pelayaran Makassar. Suharsaputra (2010) menjelaskan bahwa faktor kemampuan/kompetensi dapat mempengaruhi kinerja karena dengan kemampuan yang tinggi, maka kinerja pegawai pun akan tercapai. Sebaliknya, apabila kemampuan pegawai rendah atau tidak sesuai dengan keahliannya, maka kinerja pun akan sulit tercapai. 


\subsection{Pengaruh Motivasi Kerja terhadap Kinerja Pegawai pada Badan Pengembangan Sumber Daya Manusia Daerah Provinsi NTT}

Hasil uji statistik menunjukkan bahwa nilai probability yang diperoleh adalah sebesar 0,000 $(<0,05)$, sehingga keputusannya adalah motivasi kerja berpengaruh positif dan signifikan terhadap kinerja pegawai. Hasil penelitian ini sejalan dengan penelitian yang dilakukan Bimo (2016) dengan judul: "Pengaruh Kompetensi, Motivasi dan Budaya Organisasi Terhadap Kinerja Karyawan Pada Dinas Kebudayaan dan Pariwisata Kabupaten Probolinggo Melalui Komitmen Karyawan" yang menunjukkan hasil bahwa motivasi kerja secara parsial berpengaruh signifikan terhadap kinerja karyawan pada Dinas Kebudayaan dan Pariwisata Kabupaten Probolinggo. Seorang pimpinan hendaknya memberikan motivasi kerja dan melihat perilaku yang ditunjukkan oleh karyawan serta memilih cara apa yang bisa digunakan agar karyawan termotivasi dalam bekerja. Pemberian motivasi kerja yang sesuai dan tepat dengan kebutuhan karyawan harus dipertahankan agar karyawan dapat menghasilkan kinerja yang sesuai dengan kehendak perusahaan.

\section{KESIMPULAN DAN SARAN}

\subsection{Kesimpulan}

Berdasarkan hasil analisis yang telah dibahas, maka kesimpulan dari hasil penelitian ini adalah sebagai berikut:

1. Hasil analisis secara deskriptif menunjukkan bahwa gambaran responden tentang kinerja, motivasi kerja, budaya organisasi, lingkungan kerja dan kompetensi SDM adalah "Cukup Baik". Sedangkan gambaran responden tentang disiplin kerja adalah "Baik".

2. Hasil analisis statistik inferensial menunjukkan bahwa: Variabel disiplin kerja, budaya organisasi, lingkungan kerja dan kompetensi SDM berpengaruh positif dan signifikan terhadap motivasi kerja. Selanjutrnya, variabel disiplin kerja, budaya organisasi, lingkungan kerja, kompetensi SDM dan motivasi kerja berpengaruh positif dan signifikan terhadap kinerja pegawai.

3. Nilai koefesien determinasi (R2) menunjukkan bahwa kemampuan variabel disiplin kerja, budaya organisasi, lingkungan kerja, kompetensi SDM dan motivasi kerja menjelaskan variabel kinerja pegawai adalah sebesar $77,6 \%$; Selanjutnya, kemampuan variabel disiplin kerja, budaya organisasi, lingkungan kerja, dan kompetensi SDM menjelaskan variabel motivasi kerja dalam penelitian ini adalah sebesar $59,6 \%$.

4. Hasil uji Specific Indirect Effect menunjukkan bahwa motivasi kerja berpengaruh positif dan signifikan dalam memediasi pengaruh disiplin kerja, budaya organisasi, lingkungan kerja dan kompetensi SDM terhadap kinerja 
ASN pada Badan Pengembangan Sumber Daya Manusia Daerah Provinsi Nusa Tenggara Timur.

\subsection{Saran}

Berdasarkan kesimpulan hasil penelitian ini, maka disarankan kepada manajemen Badan Pengembangan Sumber Daya Manusia Daerah Provinsi Nusa Tenggara Timur beberapa hal sebagai berikut.

1. Meningkatkan motivasi kerja, dengan cara memberikan kondisi kerja yang nyaman bagi pegawai.

2. Meningkatkan disiplin kerja, dengan cara menegaskan kepada tiap pegawai untuk mematuhi prosedur kerja yang berlaku dalam organisasi.

3. Meningkatkan budaya organisasi, dengan cara membangun semangat kerja sama antar pegawai, antar bidang kerja.

4. Meningkatkan lingkungan kerja, dengan cara mengarahkan pegawai untuk menjaga hubungan baik antara sesama rekan kerja.

5. Meningkatkan kompetensi SDM, dengan cara menegaskan kepada tiap pegawai untuk bersikap positif dalam menerima tugas dengan baik

\section{DAFTAR PUSTAKA}

Afandi, P. 2018. Manajemen Sumber Daya Manusia (Teori, Konsep dan. Indikator). Riau: Zanafa Publishing.

Edison, Emron. 2017. Manajemen Sumber Daya Manusia. Bandung: CV. Alfabeta.

Fahmi, Irham. 2016. Manajemen Sumber Daya Manusia. Teori dan Aplikasi. Edisi Revisi. Bandung: CV. Alfabeta.

Hasibuan, Malayu. 2016. Manajemen Sumber Daya Manusia. Jakarta: PT. Bumi Aksara.

Levis, Leta Rafael. 2013. Metode Penelitian Perilaku Petani. Yogyakarta: Ledalero

Mangkunegara, A.A Anwar Prabu . 2017. Evaluasi Kinerja Sumber Daya Manusia. Bandung: PT. Refika Aditama

Robbins, Stephen P. 2009. Manajemen Jilid 1. Edisi Kesepuluh. Jakarta: Erlangga.

Sedarmayanti. 2007. Manajemen Sumber Daya Manusia. Bandung: Refika Aditama.

Simamora, Henry. 2019. Manajemen Sumberdaya Manusia. Yogyakarta: Sekolah. Tinggi Ilmu Ekonomi YKPN.

Simanjuntak, Payaman J. 2011. Manajemen Evaluasi Kinerja. Jakarta: Fakutas UI. 
Sutrisno, Edi. 2009. Manajemen Sumber Daya Manusia. Jakarta: Kencana Prenada Media Group.

Tika. 2013. Budaya Organisasi. Jakarta: PT. Raja Grafindo Persada.

Uha, Ismail Nawawi. 2013. Budaya Organisasi Kepemimpinan dan Kinerja. Jakarta: Kencana

Winardi. 2002. Motivasi dan Pemotivasian dalam Manajemen . Jakarta: PT. Raja Grafindo Persada. 